\title{
Understanding the Different Facets of the Human Person
}

\author{
Gerishon Kuria Njuguna \\ Senior Lecturer \\ Egerton University \\ Faculty of Arts and Social Sciences \\ Department of Philosophy, History and Religious Studies \\ P. O. Box 536-20115, Egerton, Kenya
}

\begin{abstract}
The term "person" is controversial both in origin and meaning. The researcher explicates the etymology and meaning of "what is a person?" Philosophical views onwhat constitutes personality have been explored. Relational, dialogical and global concept of the person, the person as the seat of the spirit, and human personality has been discussed. It is establishedthat the term 'person' did not have any philosophical meaning until the patristic and scholastic periods, when it was used to clarify Christological controversies. Further, this concept may be understoodon the basis of consciousness, dynamism, relationships, rationality, ideas and impressions, actions, transcendent/spiritual nature, and an interaction between body and spirit. The study concludes that the human person is dynamic, open to future and his actions, and being spiritual transcends motion and time. The person is an entity and not just a concept, and a whole not just a part and constitutes existence and intellectual nature.
\end{abstract}

\subsection{Introduction}

The paper is concerned with the notion of the "person" as a concept. Controversial as the concept is, this paper attempts to address the question 'What is a person?'The researcher wishes to explicate this concept by first understanding the etymological origin of the term person. Diverse views of various philosophers; medieval, modern and contemporary, and their understanding of what constitutes personality have been explored and discussed. Further, the paper delves on the relational, dialogical and global concept of the person, the person as the seat of the spirit, andthe idea human personality. This study establishes that the term "person" has various meaning depending of the context in which its defined.

\subsection{The Notion of the Human Person}

The origin of the word 'person' is nearly as controversial as its meaning. Analysing the etymological definition of the term person, Okemwa (1997) opines that the Latin 'persuonare', that which 'sounds' in the mask, is significant in so far as it points to the reality of dynamism of action as opposed to at rest, dormant or passive.

To Mondin (1985), the term person not only connotes substance, but also that substance is marked out in the characteristics of acting as dynamism.

Historically the meaning of the word persona or its Greek equivalent prosopon was that of disguising. That is, the person is not only a fruit of biological events. The person has an inner or psychological or spiritual dimension which is disguised in the concrete being. Therefore, a person is not only an outward bodily form but is also the subject of consciousness and a force capable of thought and experience (Mondin 1985).

In this study the word used as equivalent of person is $m t u$ in Kiswahili or mundu among the Gikuyu people.In the Bantu worldview, the word muntu inherently includes an idea of excellence or plenitude (Tempels 1969). In addition muntu is always, in a relation of being to being with God, with his clan brethren, with his family and with his descendants. He is in a similar ontological relationship with his patrimony, his land and with all that it contains or produces, with all that grows or lives on it.It is clear that apart from muntu being a human being; he stands also for certain properties of lived experiences. In this regard, Tempels (1969) observed that the Baluba can say, "this is not a muntu", of a man who behaves unworthily.According to him 'Muntu signifies, vital force, endowed with intelligence and will.

\subsection{Theological Background}

It is generally agreed that the original meaning of the word person did not, at least explicitly, connote something philosophical until the church Fathers during the patristic and scholastic periods employed the word and gave it a more specific meaning. 
This was an attempt to clarify Christological controversies regarding the incarnation, the mystery of the quarrel concerning the Trinity. The Nicene Council had realized the ambiguity of the term person. It is from this ambiguity that the term 'person' became an area of continuous research.

In his analysis of the term "person" Mondin (1985) observes that until the advent of Christianity, there did not exist in Greek or in Latin, a word to express the concept of person because in pagan culture such a concept did not exist. These cultures did not recognize the absolute value of the individual as such, and made their absolute value depend essentially on class, rank and race.

Hecritically argues further that holistically the word 'person' marks the line of demarcation between pagan and christian culture.

\subsection{Philosophical Understanding of the Term Person}

Various philosophical definitions of the term person have been put across.

\subsubsection{Boethius}

In his philosophical treaties, contra Eutichen et Nostorium, Severin Boethius says that a person is an individual substance of a rational nature.In this classical definition we note that not every substance is a person. Okemwa (1985) quoting Boethius says that substance might seem to be predicated of God, not because he is set under other things like a substrate but because, just as he is before all things, so he as it were the principle beneath al things, supplying them with all Osisiosthai or subsistence. Only individual substances of a rational nature are. The key part of this definition is the expression; 'rational nature', which means 'person' is predicated only of intellectual being. Rationality depicts a kind of a nature which confers upon a person the ability to act in a rational manner.

This rationality makes a person be able to determine himself, have freedom to choose good or evil, his end and means of attaining that end.

\subsubsection{Thomas Aquinas}

Thomas Aquinas sees the person as a hypostasis for first substance, distinguished by its rational or intellectual nature, which impliesdominion over its own action. He explains the term 'person' asa substance, complete, subsisting per se, existing apart from others. This means that the person exists in himself and for himself,he is the ultimate possessor of his nature and all its acts, and the ultimate subject of predication of all his attributes. Aquinas expounds this understanding of the person of a person and observes that because of the fact that the person hood involves selfsubsistence and the possession of a complete rather than a partial human nature, the soul cannot be considered a person, even when existing separately. In the same vein due to the fact that the human nature of Christ subsists not on its own, but in the person of the word of God, it too cannot be called a person (Geddes 2011).

Aquinas further says that because of this complete and self-subsisting character, there is a definite incommunicability or uniqueness of the person. He defines the person as that which is most perfect in the whole of nature, namely, to that which subsists in rational nature.

Aquinas observes that the human person is dynamic because the person is open to future, and his actions being spiritual transcend motion and time. At the same time the person is an entity and not just a concept, and a whole and not just a part. He underlines that existence and intellectual nature (essence) are constitutive of a person. He argues out, that the activities of a person are not constitutive of the person but come as a result of the being of the person. The researcher views Aquinas definition of person as more convincing and encompassing.

\subsubsection{Rene Descartes}

Rene Descartes, the father of modern philosophy defines the person in relation to self-consciousness rather than in its autonomy, substance or unity of body and soul. Man, for him is essentially thought, ego. Descartes' definition goes against all metaphysical, logical or ontological premise. Thought precedes being. One cannot think before he exists, one has to exist in order to think. We advocate the priority of being over having and existence over thought. At the same time, identifying the person solely as one with self-consciousness, deprives all others without consciousness personality like babies who have not yet reached the age of reason, the sleeping and the comatose. This is a wrong anthropology with far reaching negative moral consequences. This is another area of contention in African political philosophy.

\subsubsection{John Locke}

Locke (1836)defines a person as a thinking intelligent being that can know itself as the same thinking thing in different times and places. Therefore consciousness is the experience which creates personal identity, this is because a person has the properties of being conscious, self aware and rational.This consciousness covers current mental states, awareness of our own bodies, and awareness of the past. 
Person therefore is a forensic term, involving praise and blame, and a capacity to obey laws. Though Locke was somewhat inconsistent, the standard way to understand him is to note that he distinguished the identity of being a man (human) that consists in the "continuity of a living organized body from the identity of a person that consists in the 'continuity' of consciousness and psychological traits, especially memory.

\subsubsection{David Hume}

Hume (1961) distinguishes between the human being and the human person. The human being is composed for him of both the body and the mind, whereas the human person is the same as the self, the mind, or the soul. What makes up a human person according to Hume are ideas and impressions; but they prove to be problematic to the degree where we wonder whether the human self is a logically viable entity. According to Hume the difference between impressions and ideas only come through introspection.

\subsubsection{Immanuel Kant}

Kant (1996) defines a person as a rational being whose nature already marks him as an end in itself that is as an object of respect.In the Metaphysics of Morals, Kant describes a person as a subject whose actions can be imputed to him. Moral personality is therefore nothing other than freedom of a rational being under moral laws.Kant consideres the term person to be applicable to beings with certain capacities rather than beings who are members of a certain species.Kant emphasizes that this capacity is the rational nature simplicter which must be exercised in a certain manner. When Kant says that human beings ought to be rational, that their true nature is to be rational, he means that reason cannot be just a means to better achieve non-rational goals, but that rationality must be an end, a desirable goal in itself. Kant observes that a human being has a duty to himself to cultivate his natural powers (powers of spirit, mind, body), as means to all sorts of possible ends.

\subsubsection{Donceel}

Traditionally, a person, according to Donceel (1967) is defined as, an individual possessing a spiritual nature. According to him, this definition contains a genus :( individual) and a specific difference possessing a spiritual nature. Thus, far, it could be said then that generally, in his very nature the human person is a rational cum spiritual being and because of these qualities, he is also a moral being. On this Donceel opines that all real beings are individual; general entities (universals) exist only in the mind. But all real beings are not individualized in the same way.For him, man is one in himself and distinct from all other beings through the very fullness and infinity of his being.

\subsection{The 'Dialogical' Concept of Person}

The person is a relational being; he has the capacity to have interpersonal relationship with others in his community. According to Mondin (1985)this has three basic characteristics; vocation, action and communication. Vocation is a characteristic of person and means that every individual person has a unique and particular meaning for his existence. Action implies that the person is always in a continuous and dynamic activity aimed at actualizing himself. Communication implies encounter with others, the movement towards others. Dialogue requires each person to see other person as the 'other.' The other person in communication is seen as another, an absolutely different person, whom I encounter as an enigma being aware of the fundamental otherness of the other.

According to Lenfers (1989) whenever one human being meets another there lies the chance of a personal encounter, springing from the immediate perception that here a free being is facing a free being like himself.

\subsubsection{The Relational Concept of the Person}

According to (Marcel 1973) this is the intersubjectivity that exists between a subject and another subject. It is the relationship that the 'I' shares with the other subject regarded as 'Thou' in which the subject ego recognizes the other as a fellow person. The other person in our life becomes unavoidable. The 'Thou' here represents concrete individual being who ought to be respected and valued.The 'Thou' is not imagery figure like that of Hegel's 'Absolute Spirit' or that of Descartes' 'Thinking Ego." In this relationship, the 'I' is not suspicious of the "Thou', they don't enslave each other, there are no dangers, conflicts, shame, alienation, enslavement and negativity in their relationship.

Gonzales (1983) throws some light on this issue when he says that human love in its fullest sense is an experience of inter-subjectivity. It passes beyond the I-It and the I-He/She relation to an I-Thou relation...He or she is someone else standing over there about whom we are talking: we communicate about but not with him or her.

\subsubsection{Person as a Unity and Complexity}

One fundamental concern of existential philosophy is the concrete man in his concrete situation. The experience and understanding of person as a unity helps us to understand man's complex and ontic nature (Wojtyla 1979). This intensive unity of man becomes fully visible only in the fact of man being self conscious. Human actions and reactions are centred in an ego which binds the multiplicity of activities and experiences together into a single life history. 
lenfers (1989) argues that as the agent of human activity, the self emerges enduring in continuous identity with itself, distinguished from everything else, giving coherence to the manifold events affecting man, unifying all occurrences in a framework of meaning, subject to a process of growth that aims at being more oneself through an ever integration of the human being.

Man's extensive unity is also unrivalled by reason of its infinitude. Man's tendency to surpass all restriction shows itself not only in the conquest of all places of this earth and its surrounding space but also in his exploration of the remotest past up to the first seconds of the constitution of the universe and of its likely future developments(Lenfers 1989).Man's endless extension reveals itself especially in his concept of totality which includes absolutely everything. His field of relationships is thus without limits. Man can occupy himself with anything whatsoever. He is related to all being.At the same time man as a subject is moved by the fundamental question of his own person. He is concerned with himself, other persons and any other reality outside himself. This need to experience oneself leads to vital questions. Some of them being; whom am I? Am I free to experience and to be myself? Do I experience appreciation, selfconcept, respect of my own worth.

Once man is able to answer these questions in the affirmative, then he is able to face himself in a cognitive sense. This is why it is important to face/consider man as a whole, as a 'unit of meaning' with the aim of helping the human being to understand himself better and identify the characteristic traits of his existence. Today, even with scientific, philosophical and even theological developments, we don't have a clear and consistent idea of man's nature and reason for his own existence. Man has created his own world, a world that conditions and recreates him and thwarts his own image. He has been reduced to a passive recipient and consumer of his own scientific products and this determines his own destiny. This man has ceased to be an end but a means to his own material and scientific ends. Man has turned to be materialistic and consummerist, not valued for what he is but rather for what he produces and consumes. In the world we live in the only value we strive for seems to us to be material, wealth and pleasure without metaphysical backup and values. We are in a materialistic world less of spiritual foundation. According to Scheler (1961) conscious of our own reality, we ask the question: what is man? This question invites us to interrogate his nature and place in the world that we seem to have created ourselves. This invites us to develop an anthropology that takes man to search for his own self, to have the experience of himself and experience the reality around him. To this end we could affirmatively say that in no other period of human knowledge and history man has never become more problematic to himself than our days (Scheler 1961).

\subsubsection{Substantial or Individual Concept of Person}

The substantial or individual concept is divided into two: the ontological and psychological concept of 'person'. By ontological concept we mean that the person is defined by his singularity as unique, concrete, incommunicable and unrepeatable individual substance of rational nature.

By individual substance, it means an entity that exists in and by itself in space and time, a whole and undivided thing. However not all individual substances that exist are persons.

Another property of the person is that of incommunicability (Aquinas).This means that the individual who is a person cannot communicate with other things as a part, being a complete totality, and he cannot communicate as a universal communicates with the individuals, in that the person is something assumable. It is because of this incommunicability that distinguished him both from essence and nature(Mondin 1985).

\subsubsection{The Human Person as Endowed with Ability for Self-Transcendence}

Inherent in the human person is the urge to go beyond all previous achievements; one is always unsatisfied with results already acquired. Life is characterized by an essential 'going beyond' the factual situation; one can never say that this much and no more is enough of what is required of the person. In this sense, personhood is self-transcendent.

The tendency manifests itself not only in the endeavour of coming to know the truth and the full truth, but in many other ways. Whatever is partial leaves man dissatisfied and keeps him on the move towards the less partial and more complete. In all this striving man in stretching out towards something which he can neither find nor hope to find among the things of this world. He is directed towards a goal beyond all the particulars of this world and beyond the sum total of all those particulars. This is why man is said to be "a metaphysical being." This inherent ability to transcend all that is limited and partial we call transcendence. Any being that is able to transcend is said to be "spiritual". Spiritual means "able to transcend (Lenfers 1989). The self-transcendence is the spiritual element in the person. And being spiritual nature, it is totally independent of the body (but not opposed to it) and different in its mode of operation. This means then that comprehensive definition of person must include four fundamental elements: autonomy in being, self-consciousness, communication and self-transcendence. 
Consequently a person can be defined as a subsistence gift with self-consciousness, communication and selftranscendence (Mondin 1985). Through self-consciousness he recognizes himself as unique and unrepeatable but at the same time free, social and perfectible, through communication he enters into relationships with others. Through his consciousness the same body reaches out of himself and opens up to the world around him. This same body becomes a means of communication with the self, the world and others. Hence, there is an anthropological and existential need to consider the person in his integral nature.

\subsubsection{Person as a Unity of Acts of Different Natures}

The person carries out many acts and activities (willing, feeling acts, valuing etc). He does so by knowing and freely choosing because the intellect and will interact.Scheler (1961) for instance, sees the person in his internal processes of the conscious intellect, of a feeling, emotional and acting individual substance of a rational nature, the bearer of values. He puts this idea plainly and says: "But the identification of the "a priori" with "thought" and a priorism with "rationalism" as Kant (1996) would have it, leads yet to another basic fallacy, one that is especially detrimental to ethics.

A person does not consequently manifest himself only as a pure rational being but also as emotional being and reveals himself through his own acts. The person is a unity of acts of different nature and it is exactly such, diversity that is essential for the being of the person. A person understood in this way varies and is differentiated through his actions without becoming exhausted by anyone of these acts.

Scheler (1961) opines that the person entirely gives himself in each act but without exhausting what he really is in them; he transcends his actions at the same time, he becomes and reveals himself through his actions. It is through his actions that he experiences himself at the same time. To Scheler (1961), a person therefore is the unity of acts of different natures (like loving, remembering, thinking, willing, perceiving, judging feeling etc) of inner intuition in which everything psychic becomes objective. It is only through his activity, his relationship with himself, with other person in his world and the absolute, that he develops and actualizes his being as a person; he becomes a personality.

The person is what he acts. If one acts good he is good and if one acts bad, he is bad. Pat Kelly quotes Aristotle that one is good by practicing good deeds, bad by practicing bad deeds, brave by practicing brave deeds and temperate by practicing temperance (Kelly 1978). Wojtyla (1959) argues that while performing good deeds, the human person becomes good; while performing morally wrong actions, the subject becomes morally corrupted.

\subsection{Person as Seat of the Spirit}

The term "spirit" comes from the Latin 'Spiritus' meaning 'breath'. The spirit of a living thing usually refers to or explains consciousness (reflective consciousness). Because of this consciousness, man is able to think, acquire knowledge, and justify his knowledge or even doubt. Consciousness is a mental activity which is always inside us. The activities of consciousness include thinking, believing, knowing, imagining, seeing, listening, feeling, deliberating, deciding, choosing, loving, liking, hating, desiring etc.

The person is always in search of knowledge, he looks for meaning in his life in matters of faith, support, justice, freedom, responsibilities etc. At the same time his spiritual nature leads him search for spiritual values. Hence there is emancipation of spiritual knowledge from environmental pressures and interests. Spirit is the ability to placing one's living space with its selected centres of attraction and resistance into an extended context, that objectives that space and transforms one's environment into a lived world.

According to this view the birth of man and the birth of God are, from outset, reciprocally dependent upon each other (Scheler 1961). In the journey towards the absolute being, the fundamental value is the spirit. The person lives in a state of continuous tension directed towards the origin of his existence.

\subsubsection{The Human Person as a Rational Individual}

By one's very nature a person is a rational or capable of reasoning. Reason is the power to calculate, reflect, and know, to understand relations and universal qualities, to live by the rule instead of being swayed by appetite. It is an essential human attribute that differentiates a person from other beings. He is a concrete existing being, clearly observable, undivided in oneself and separated from others and unrepeatable. It is important to acknowledge the uniqueness and unrepeatability of the human persons they serve and work for rationality and individuality point to the dignity of the human persons as possessors of rights, who must always be respected as beings of infinite value in themselves.

\subsubsection{The Human Person as a Unity of Body and Spirit}

The human person is a unity of body and spirit. Ontologically the person is one, a whole constituted of not only single, but dual principles. The body is essentially determined by the spirit and vice versa. Of the two, primacy belongs to the spirit and not to the body. 
This is because the spirit is the formal cause of the body; it is the giver of meaning to the whole person. It is important to note that meaningful development of each aspect calls for a serious interpenetration of both.

Unfortunately, in Africa today there is a tendency to pay more attention to generating material values to satisfy the person's bodily nature at the at the cost of neglecting the spiritual dimension. This is a lopsided kind of development because no human endeavour which ignores the ontological unity of the human person can claim viably to promote the welfare of humanity since any viable progress of the human person essentially implies fulfilment of the whole person.

\subsection{Personality Versus Person}

Personality is a very complex structure whose operation can be understood in terms of powers both material and immaterial. These interact with each other in ways that cannot be fully comprehensible(Ibuanyidanda 2005). Allport (1961), however, defines personality as the dynamic organization within the individual, of those psychophysical systems that determines his characteristic behaviour and thought.This means that personality refers to patterns of thought, feelings and behaviours consistently exhibited by an individual over time that strongly influence our expectations, self perceptions, values and attitudes and predicts our reactions to people, problems and stress. It is a combination of emotional, attitudinal and behavioural response patterns of an individual. Personality is not just who we are but how we are. This makes the person unique because personality arises from within the individual and remains consistent given that essentially people act in the same ways or similar ways in variety of situations.

Personality understood as an organization is dynamic, it changes, it acts upon the environment and is influenced by it. These systems are psycho-physical, they have a bodily and a mental aspect. This dynamic organization determines the behaviour and thought of the individual. The way in which a person behaves and thinks is determined and explained by his personality- by the way these psycho-physical systems are organized in him.It is important to note that no two people are exactly the same- not even identical twins. Some people are anxious, some are risky taking, some are phlegmatic, some highly strung, some are confident, some shy and some quiet and some loquacious. This is all because of different personalities.

\section{Conclusion}

We have established that the term 'person' did not have any philosophical meaning until the patristic and scholastic periods, when it was used to clarify Christological controversies. We have established that the human person is dynamic. The person is open to future and his actions and being spiritual transcends motion and time. The person is an entity and not just a concept, and a whole not just a part. Existence and intellectual nature are constitutive of the person. Lastly we have looked at the nature of the person in terms interiority, inwardness-self presence, subjectivity, inter subjectivity, solitude and communion.

\section{References}

Allport, T. W.,(1961), Pattern and Growth in Personality, New York: Holt Pub.

Clark, T. D. B., "A Defence of the Thomistic Definition of the Person," http://www.gocart.org/thesis.html

David H., (1961), A Treatise of Human Nature, Garden City, New York: Doubleday \& Co., Inc., Dolphin Books.

Donceel, J. F., (1967), Philosophical Anthropology, Kansas City, Sheed Andrews and Mcmeel Inc.

Geddes, L., Person in the Catholic Encyclopedia, New York: Robert Appleton Company, Retrieved November 1, 2011 from New Advent: http://www.New Advent.Org/Cathen/11726a.htm>.

Gonsalves, M. A. and Fagothey, A., (1989), Fagothey's Right and Reason: Ethics in Theory and Practice, Merril Publishing Company.

Hume, D.,(1961) A Treatise of Human Nature, Garden City, New York: Doubleday \& Co., Inc., Dolphin Books.

Locke, J., (1803), An Essay Concerning Human Understanding, Boston, David Carliste.

Ibuanyidanda, I. A., (2005), The Methods and Principles of Complementary Reflection in and beyond African Philosophy Lit Verlag, Munster.

Kant, I., (1996), The Metaphysics of Morals, Volume 16, New York, Cambridge University Press.

Kelley,P., (1978), Aristotle's Moral Philosophy, London: Blueprint Press.

Lenfers D., (1989), The Marvel of Human Being, Dublin: Dominican Publications.

Marcel G., (1973), Tragic Wisdom and Beyond, trans. Stephen Jolin and Peter McCormick, Evanston: Northwestern University Press.

Mondin,B., (1985), Philosophical Anthropology Man: An Impossible Project? Rome: Urbaniana University Press.

Okemwa, J., (1997), Self Determination and Freedom in the Acting Person by Karol Wojtyla, (Nairobi, Pauline Publications Africa.

Scheler, M.,(1961), Man's place in Nature, New York: Noonday Press.

Saint Thomas Aquinas, Summa Theologiae, 1 - 11, 1, Prologue 1, q, 29,a.1

Tempels, P., (1969), Bantu Philosophy, Paris: Presence Africaine. 